\title{
FENOMEN UDZIAŁU OCHOTNIKÓW Z REPUBLIKI TRYNIDADU I TOBAGO W SZEREGACH TZW. PAŃSTWA ISLAMSKIEGO
}

\author{
Stanisław Kosmynka \\ Uniwersytet Łódzki \\ Wydział Studiów Międzynarodowych i Politologicznych \\ Katedra Studiów Latynoamerykańskich i Porównawczych \\ e-mail: skosmynka@uni.lodz.pl \\ ORCID: https://orcid.org/0000-0003-4131-4762
}

\begin{abstract}
Streszczenie: Celem artykułu jest próba odpowiedzi na pytanie, dlaczego z niewielkiego karaibskiego kraju - Republiki Trynidadu i Tobago - wyruszyła spora liczba kandydatów na bojowników do tzw. Państwa Islamskiego oraz jakie jest społeczno-ekonomiczne podłoże radykalizacji części młodych muzułmanów zamieszkujących tworzące to państwo wyspy. Analiza zawiera refleksję nad wyzwaniami dla bezpieczeństwa, generowanymi przez mający zasięg globalny swoisty ruch społeczny, za który może być uważany dżihadyzm. Przypadek położonego nieopodal Wenezueli Trynidadu i Tobago obrazuje niezwykle ważny aspekt, określający te wyzwania - związki terroryzmu z mającymi charakter transnarodowy sieciami przestępczości zorganizowanej.
\end{abstract}

Słowa kluczowe: Trynidad i Tobago, dżihadyści, tzw. Państwo Islamskie, antyterroryzm, przestępczość

Współczesny charakter zagrożeń dla bezpieczeństwa, kształtowany w dużym stopniu przez ekstremizm dżihadystyczny, najdobitniej egzemplifikuje przypadek powstania i działalności tzw. Państwa Islamskiego. Samozwańczy kalifat, który ustanowiła ta organizacja wraz z szerokim wachlarzem zręcznie przygotowanych materiałów propagandowych, zamieszczanych w przestrzeni wirtualnej, okazały się być magnesem przyciągającym wielu ochotników nie tylko pochodzących $\mathrm{z}$ terenów kontrolowanych przez ten twór, ale również z różnych, czasem bardzo odległych zakątków świata.

Akces do udziału w „wojnie z niewiernymi” zgłaszali głównie młodzi wyznawcy islamu, wywodzący się m.in. z państw muzułmańskich bądź europejskich pod wpływem różnych czynników. Osobników tych cechuje przede wszystkim 
szczególna podatność na narrację prowadzoną przez nurty radykalne. U schyłku 2017 roku oceniano, że na terenie Syrii i Iraku szeregi organizacji dżihadystycznych gromadziły ponad 30 tys. pochodzących z zagranicy bojowników (tzw. foreign fighters), w tym ok. 5 tys. przybyłych tam z Europy [García-Calvo 2017]. Na tereny kontrolowane przez rozbite obecnie w swym mateczniku tzw. Państwo Islamskie docierali także jego sympatycy z innych regionów, np. Azji Południowo-Wschodniej i Afryki, a także, choć w znacznie mniejszym zakresie - z innych części świata. Z Ameryki Łacińskiej i Karaibów zdecydowanie największa liczba młodych muzułmanów wyruszyła do Syrii i Iraku z niewielkiego, liczącego ok. 1,2 mln mieszkańców państwa - Republiki Trynidadu i Tobago. W 2017 roku oceniano, że nawet stu kilkudziesięciu obywateli tego kraju udało się w podróż do Syrii i Iraku, by wesprzeć tzw. Państwo Islamskie [Combatientes de Trinidad y Tobago... 2017]. John McCoy i W. Andy Knight szacują tę liczbę w granicach 89-125 osób. Dla porównania w szeregach tzw. Państwa Islamskiego znajdowało się ok. 250 ochotników wywodzących się z liczących ok. 320 mln mieszkańców Stanów Zjednoczonych Ameryki [McCoy, Knight 2017]. Dodajmy, że liczba ochotników wywodzących się z innych państw karaibskich oraz z regionu Ameryki Łacińskiej jest śladowa, tym bardziej więc powyższe dane świadczą o swoistym fenomenie i skłaniają do zastanowienia się nad uwarunkowaniami tego zjawiska.

Najważniejsza wydaje się próba odpowiedzi na pytanie, dlaczego z tego niewielkiego kraju wyruszyło tak wielu kandydatów na dżihadystów oraz jakie jest społeczno-ekonomiczne podłoże radykalizacji niektórych spośród muzułmanów zamieszkujących tworzące to państwo wyspy. Celem tego artykułu jest próba odpowiedzi na te pytania. Analiza tu zawarta podejmuje refleksję nad wyzwaniami dla bezpieczeństwa, generowanymi przez mający zasięg globalny swoisty ruch społeczny, za który może być uważany dżihadyzm. Przykład położonego nieopodal Wenezueli Trynidadu i Tobago obrazuje kolejny niezwykle ważny aspekt określający te wyzwania: związki terroryzmu z mającymi charakter transnarodowy sieciami przestępczości zorganizowanej. Zależności te są widoczne w wielu regionach świata, m.in. Europie i Afryce Północnej.

Metodologia badań nad terroryzmem wskazuje na potrzebę doboru interdyscyplinarnego wachlarza metod [Bolechów 2012]. Próba odpowiedzi na pytanie, dlaczego z niewielkiego wyspiarskiego państwa na Karaibach wywodzi się tak pokaźna liczba ochotników do ruchu globalnego dżihadu implikuje zastosowanie metody systemowej, pozwalającej na diagnozę badanych zagadnień jako splecionego zespołu elementów, w ramach którego uwaga skupiona jest zarówno na ich częściach składowych, jak i wzajemnych powiązaniach - szczególnie w kontekście uchwycenia relacji przyczynowo-skutkowych, krystalizacji określonych elementów i przesłanek zagrożeń dla bezpieczeństwa. Śledzenie procesu przeobrażeń współczesnego terroryzmu unaocznia, jak ważne miejsce zajmuje wpisująca się w wymiar ruchów społecznych teoria sieci, które to pojęcie nawiązuje do prac Marca Sagemana. Postrzega on komórki dżihadystyczne jako swoisty ruch społeczny, złożony z licznych nieformalnych sieci inspirujących do terro- 
ryzmu, zarazem jako pewną formę organizacji [Sageman 2008]. Aspekt diagnostyczny i weryfikacyjny metody systemowej również nawiązuje w tym ujęciu do tych koncepcji w kontekście analiz społecznych i ekonomicznych uwarunkowań procesu radykalizacji. Wskazuje też na fenomen determinacji niewielkich grup społecznych i pojedynczych osób, manifestujących skrajnie salaficki dyskurs i kierujących się specyficznym systemem aksjonormatywnym.

W sierpniu 2017 roku premier Republiki Trynidadu i Tobago Keith Rowley uznał związki radykalnego islamu z czerpiącymi profity z ,prania brudnych pieniędzy", wymuszania haraczy, porwań, handlu bronią i substancjami psychoaktywnymi grupami przestępczymi za poważne wyzwanie dla bezpieczeństwa kraju. Stwierdził on, że: „Na problem infiltracji islamistycznej oddziałuje imigracja z pogrążonych w konflikcie państw arabskich oraz przyjęcie setek muzułmanów z Wenezueli, którzy - chociaż legitymują się paszportami wydanymi przez Caracas - to i tak nasuwają poważne wątpliwości co do ich rzeczywistego pochodzenia" [Combatientes de Trinidad y Tobago... 2017]. Wypowiedź ta sugeruje egzogenny charakter pojawienia się ekstremizmu dżihadystycznego na wyspach i zda się pomijać fenomen konwergencji działalności o profilu przestępczym z fenomenem „rodzimego terroryzmu”.

Republikę Trynidadu i Tobago charakteryzuje znaczne zróżnicowanie etniczne; jej społeczeństwo tworzą potomkowie przybyszów z Afryki, Europy i Azji. Według spisu demograficznego z 2011 roku społeczności pochodzenia afrykańskiego oraz indyjskiego stanowiły aż ok. 70\% populacji Trynidadu i Tobago, ponad 20\% określana była jako „ludność mieszana” [Lewandowska 2014]. Pojawienie się wyznawców islamu w tym karaibskim państwie miało miejsce już w minionych stuleciach; proces ów charakteryzują trzy główne wymiary [Halima-Sa'adia 2017]. Otóż osiadła tam społeczność muzułmańska (ok. 104 tys., a więc $6 \%$ ogółu populacji) zamieszkuje głównie Trynidad i w dużym stopniu wywodzi się z zachodnich Indii. Jej przodkowie w XIX wieku byli tam sprowadzani do pracy - wyspy te stanowiły kolonię brytyjską (wcześniej francuską) [Khan 2013]. Dopiero w drugiej połowie XX wieku Trynidad i Tobago uzyskał niezależność, stając się od 1976 roku republiką - wcześniej wchodził w skład Brytyjskiej Wspólnoty Narodów. Spora część zamieszkujących to wyspiarskie państwo muzułmanów ma także korzenie afrykańskie. Jak wiadomo, w minionych wiekach rdzenna ludność z tego kontynentu trafiała do Ameryki Łacińskiej w charakterze niewolników. Sprowadzano ich do pracy na plantacjach trzciny cukrowej i tytoniu. Na Trynidad i Tobago docierali też arabskojęzyczni imigranci $\mathrm{z}$ regionu Lewantu. W ciągu ostatnich lat widać kontynuację tradycji osiedlania się na wyspach imigrantów przybywających tam przede wszystkim z pogrążonej w poważnym kryzysie politycznym i gospodarczym Wenezueli, ale także z obszarów odległych geograficznie i kulturowo, m.in. z krajów afrykańskich, Bliskiego Wschodu i Chin.

Warto podkreślić, że na tle regionu Karaibów Trynidad i Tobago jest państwem wysoko rozwiniętym gospodarczo. Znaczne wpływy do budżetu są ge- 
nerowane przez rozwój sektorów przemysłowego (złoża gazu i ropy naftowej) i finansowego oraz branżę turystyczną. Pomimo tego ów kraj boryka się z wyzwaniami, będącymi udziałem tak wielu innych latynoamerykańskich państw - drobną i zorganizowaną przestępczością. Spadek cen ropy wywarł wpływ na gospodarkę kraju i przyczynił się do wzrostu nierówności społecznych. Aktywność gangów, nakręcająca spiralę przemocy, i destabilizacja kraju skłoniły władze Trynidadu i Tobago w 2011 roku do wprowadzenia stanu wyjątkowego i zaangażowania wojska w walkę z grupami kryminalnymi. Według informacji wywiadu, środowiska te planowały zgładzenie ówczesnej premier Kamli Presard-Bissessar i innych polityków. Aresztowano setki członków organizacji przestępczych. Podjęto też kroki w kierunku usprawnienia działań policji, na funkcjonowanie której przeznaczono dodatkowe środki finansowe.

Dzięki zastosowaniu zdecydowanych metod udało się powstrzymać gwałtowny wzrost przestępczości, jednak tylko przejściowo; jej wskaźniki są nadal wysokie. O skali tego zjawiska świadczy m.in. liczba rozbojów i zabójstw popełnianych na wyspach. W latach 2004-2009 zamordowano na wyspach aż 2453 osoby. Dużą ich część stanowiły ofiary gangów [Hunte, Waldropt Bonair 2010]. W 2016 roku na terenie Trynidadu i Tobago odnotowano 463 morderstwa (około 35 zabójstw na 100 tys. mieszkańców) [Dawkins 2018]. Tak wysokie wskaźniki przemocy są m.in. rezultatem walk o wpływy toczonych pomiędzy grupami przestępczymi. Co więcej, z analizy danych wynika, że poziom przestępczości, szczególnie na Trynidadzie, wykazuje tendencję rosnącą. I tak, liczbę gangów w 2006 roku szacowano na przeszło 90, podczas gdy w 2012 roku było ich już co najmniej 102 [Seepersad 2016]. Na rozwój zagrożeń generowanych przemocą w tym latynoamerykańskim państwie rzutuje także niestabilna sytuacja sąsiedniej Wenezueli, skąd trafiają na wyspy narkotyki i broń, np. w samym tylko 2015 roku skonfiskowano 691 sztuk broni palnej, w tym karabiny AK-47 [Alonso 2016]. $\mathrm{Z}$ danych policji wynika, że u schyłku 2015 roku na terenie Trynidadu i Tobago aktywnych było 147 grup przestępczych, w skład których wchodziło ok. 1700 osób. Wielu członków tychże grup, wywodzących się ze społeczności afromuzułmańskiej, przejawiało sympatie islamistyczne i podatność na hasła integrystyczne.

Należy pamiętać, że aktywizacja nurtów radykalnego islamu w tym państwie była widoczna już dekady wcześniej. W lipcu 1990 roku miała tam miejsce próba zamachu stanu. Był to przewrót polityczny przeprowadzony przez ugrupowanie Dżamaat al-Muslimin, którego przywódcą był Jasin Abu Bakr. Organizacja ta skupiała głównie potomków imigrantów z krajów afrykańskich zamieszkujących ubogie dzielnice Trynidadu, takie jak Laventille. Wraz ze 114 bojownikami Abu Bakr usiłował przejąć władzę, podkładając ładunki wybuchowe i opanowując ważne instytucje w stolicy, m.in. parlament i stację telewizyjną. Działania te spowodowały śmierć ponad dwudziestu osób. Przez sześć dni więzieni byli członkowie rządu wraz z premierem Arthurem N. R. Robinsonem. Znamienne jest to, że członkowie ugrupowania odbyli w latach 80 . XX wieku przeszkolenie wojskowe w Libii. Po niespełna tygodniu zdławiono próbę rebelii. Było to możliwe 
m.in. dzięki negocjacjom między stronami konfliktu, w które zaangażowali się ambasadorzy Wielkiej Brytanii i Stanów Zjednoczonych Ameryki.

Do próby zamachu przyczyniły się też napięcia na tle rasowym, rosnące niezadowolenie afromuzułmańskiej społeczności, której członkowie czuli się marginalizowani i dyskryminowani i już niejednokrotnie brali udział w starciach z policją. Bezpośrednią przyczyną rebelii była zaś odmowa zgody na budowę meczetu. Abu Bakr i inni uczestnicy puczu zostali postawieni przed sądem, lecz wkrótce objęto ich amnestią i odzyskali wolność. Lider nieudanego przewrotu w późniejszym czasie wielokrotnie zresztą kierował oskarżenia pod adresem władz o praktyki sprzyjające marginalizacji muzułmanów i wyrażał sympatię do tzw. Państwa Islamskiego. W jednej z wypowiedzi argumentował na przykład, że Europa nie ma moralnego prawa piętnować praktykę dekapitacji, stosowaną często na terenach samozwańczego kalifatu, z uwagi na wyroki śmierci wykonywane przy użyciu gilotyny w okresie rewolucji francuskiej [Graham Harrison, Surtees 2018].

Omawiane wydarzenia nie zakończyły bynajmniej działalności ugrupowania Dżamaat al-Muslimin. Część działaczy ruchu skierowała swe sympatie ku wspieranej przez duży odsetek społeczności afrotrynidadzkiej Narodowej Partii Ludowej. Niektórzy członkowie Dżamaat al-Muslimin na przestrzeni lat coraz bardziej ulegali oddziaływaniu idei o charakterze dżihadystycznym. I tak, w 2007 roku aresztowano trzech powiązanych z tą organizacją islamistów, planujących detonację ładunków wybuchowych na lotnisku Johna F. Kennedy'ego w Nowym Jorku [Kosmynka 2014; Connell 2004]. To właśnie ze środowisk o profilu afromuzułmańskim wywodzi się większa część sympatyków tzw. Państwa Islamskiego. Popularność islamizmu wśród tej grupy można tłumaczyć w szerszym kontekście jako pochodną międzynarodowego nurtu protestu czarnej społeczności, określanego jako ruch Black Power, rozwijającego się w latach 60. i 70. XX wieku [Causwell 2018]. Warto pamiętać, że jeden z jego północnoamerykańskich liderów, Stokely Carmichael, urodził się na Trynidadzie i działał na rzecz praw ludności afroamerykańskiej oraz był jednym z aktywistów ruchu „Czarnych Panter”.

Wspomniane wydarzenia należy postrzegać w szerszym kontekście działań na rzecz poprawy sytuacji społeczności czarnoskórej nie tylko na Karaibach, ale także w wielu państwach Ameryki Łacińskiej. Odmienności kulturowej tych społeczności towarzyszą od lat postulaty ochrony jej praw i tożsamości, zwłaszcza że ,podstawowym elementem programów organizacji afrolatynoamerykańskich są rewindykacje związane z upośledzeniem społecznym i ekonomicznym. Jest ono wyraźne nawet w krajach odnotowujących wzrost gospodarczy i odnoszących pewne sukcesy $\mathrm{w}$ walce z ubóstwem, mimo prowadzonej polityki mającej na celu likwidowanie dysproporcji między położeniem poszczególnych grup etnicznych" [Lisocka-Jaegermann 2009]. Sytuację tę w dużym stopniu egzemplifikuje przypadek Trynidadu i Tobago. W państwie tym idea Black Power inspirowała afromuzułmanów zajmujących dolne szczeble drabiny stratyfikacji społecznej do walki o poprawę położenia i przeciwstawienia się praktykom dyskryminacyjnym. Powrót do korzeni 
i swoiste przebudzenie religijne wielu jego członków charakteryzują zatem determinanty historyczne, społeczne i ekonomiczne [Terdman 2010]. Przypadek Dżamaat al-Muslimin wpisuje się w ten kontekst i obrazuje związki ruchu ukształtowanego na fundamencie haseł społeczno-ekonomicznych z legitymizującymi stosowanie przemocy ideami religijno-politycznymi. Abu Bakr identyfikował się zresztą z ruchem Black Power i postrzegał siebie jako jego sukcesora i lidera.

W społecznościach afromuzułmańskich Trynidadu i Tobago można dostrzec symptomy procesu radykalizacji, na co niewątpliwie wpływ mają - będące udziałem wielu doświadczających rasizmu, marginalizacji i braku perspektyw młodych ludzi - postawy antysystemowe, które implikują zaangażowanie w działalność przestępczą lub pobieżne zinternalizowanie idei radykalnie salafickich. Dlatego też komponentu religijnego nie należy postrzegać jako kluczowego dla decyzji o zaangażowaniu się w aktywne wsparcie tzw. Państwa Islamskiego. Ważniejsze znaczenie mają w tym kontekście nadzieje na poprawę egzystencji, konstruowanie poczucia przynależności i pragnienie nadania sensu życiu, choć oczywiście towarzyszy temu odpowiednia frazeologia nawiązująca do określonego postrzegania islamu i jego zasad. Motywację tę oddają słowa matki karaibskiego bojownika tzw. Państwa Islamskiego, At-Trinidadiego: „Jego życie jest lepsze. Ma ono jakiś cel" [Cottee 2016].

W ostatnim czasie ujawniono, że do rozpowszechniania radykalnego światopoglądu przyczyniło się oddziaływanie treści głoszonych w niektórych meczetach, np. Río Claro czy Carapo (w 2015 r. aresztowano syna przywódcy religijnego meczetu w Río Claro, zatrzymanemu postawiono zarzut zabójstwa) [El extraño caso... 2018], oraz w zakładach penitencjarnych, choć trzeba podkreślić, że współcześnie socjalizacja do dżihadyzmu jest głównie prowadzona w przestrzeni wirtualnej. Obok tego medium równoległym kanałem ekstremistycznej socjalizacji są kontakty bezpośrednie w grupach bliskich przyjaciół i znajomych. Jest to szczególnie widoczne w odniesieniu do niewielkich społeczności, w których pierwotne więzi społeczne zyskują ogromne znaczenie.

Można domniemywać, że do popularyzowania idei salafickich w tym karaibskim państwie przyczynia się także działalność prozelicka finansowana przez Arabię Saudyjską, która wysyła m.in. również do tego zakątka świata misjonarzy promujących wahhabicką wersję islamu [Cottee 2016]. Będący pokłosiem tych wpływów dyskurs radykalny nastawiony jest na wzbudzenie poczucia solidarności z cierpiącymi prześladowania muzułmanami w odległych zakątkach świata oraz pragnienie odwetu. Dla osób borykających się z problemami materialnymi, odczuwającymi nierzadko kryzys tożsamości, radykalny islam okazuje się wartością nadającą sens egzystencji i staje się filarem aksjonormatywnym. Sprawia, że jego wyznawcy identyfikują się z ideą „świętej wojny” i międzynarodowym ruchem dżihadystycznym. Zjawisko to dotyczy zresztą także konwertytów; ich liczba na przestrzeni ostatnich lat rośnie. Jednym z nich jest zresztą Abu Bakr, który przeszedł na islam na początku lat 70 . XX wieku, jak również część innych afromuzułmanów, spośród których wielu przyszło na świat w rodzinach chrze- 
ścijańskich. Dodajmy, że w społeczności afrotrynidadzkiej muzułmanie stanowią odsetek mniejszy liczebnie od chrześcijan.

Jak zauważono, dominująca część ludności wysp ma rodowód napływowy. W procesie historycznym na Trynidadzie i Tobago zaznaczyły się złożone podziały etniczne, które przez długi czas stanowiły fundament tożsamości i miały przełożenie na krystalizację odmiennych wzorców kulturowych, jak również wpływały na ukształtowanie się stereotypowego postrzegania przedstawicieli poszczególnych grup [Lewandowska 2014]. Mozaice etnicznej wysp towarzyszy różnorodność religijna - obok chrześcijaństwa (26\% populacji to katolicy) żyją tam muzułmanie i wyznawcy hinduizmu (18\%). Mieszkańcami wysp są również potomkowie imigrantów z Syrii i Libanu. W tym kontekście należy zaznaczyć, że żyjący na Trynidadzie i Tobago muzułmanie nie stanowią grupy homogenicznej. John Tofik Karam podkreślił, że fundamentem ich tożsamości jest przede wszystkim pochodzenie etniczne, a w dalszej kolejności rodzaj wyznawanej religii [Tofik Karam 2011].

W jednym z nagrań propagandowych tzw. Państwa Islamskiego, pochodzącym z 2015 roku pojawia się czterech bojowników organizacji, wywodzących się z Trynidadu i Tobago. Jeden z nich, choć wychowywał się w rodzinie chrześcijańskiej, wyznał, że „odkrył” islam, a wraz z nim konieczność walki za wiarę. Kolejny dżihadysta udał się wraz z rodziną na tereny kontrolowane przez Daesh, gdyż nie chciał pozwolić, by jego dzieci „,̇̇ły w miejscu, gdzie nie mogą być wyznawcami islamu" [El extraño caso... 2018]. Wszystkie te wypowiedzi przenika wezwanie do „świętej wojny z sojusznikami szatana”. W internetowym magazynie tzw. Państwa Islamskiego „Dabiq”, w numerze z 2017 roku, pojawia się również jeden z ochotników przybyłych z Trynidadu i Tobago, nazwany Abu Sa'd at-Trinidadi (Shane Crawford), który wyjaśnia tam, jak wraz z innymi rodakami zgromadził środki finansowe niezbędne do odbycia liczącej ponad 9,5 tys. km podróży, by zaangażować się w walkę po stronie kalifatu. W tego typu materiałach można znaleźć wypowiedzi, że Trynidad i Tobago ,jest proporcem islamu na Zachodzie". Mający przeszłość kryminalną At-Trinidadi poniósł prawdopodobnie śmierć na terenie Syrii wskutek ataku przy użyciu dronów.

Przytoczone sytuacje i zdarzenia uprawniają do przypuszczeń, że na terenie Trynidadu i Tobago może urzeczywistnić się zagrożenie terrorystyczne. Poważne zaniepokojenie budzi prawdopodobieństwo powrotu byłych dżihadystów i możliwość kontynuowania przez nich działalności terrorystycznej. W związku z podejrzeniami o przygotowanie zamachu w czasie karnawału na wyspach 8 lutego 2018 r. zatrzymano kilku muzułmańskich radykałów autoafiliujących się do tzw. Państwa Islamskiego. $Z$ oczywistych względów dla liderów grup ekstremistycznych działających na terenie Syrii i Iraku pozyskanie muzułmanów z tak odległej, a zarazem strategicznie położonej części świata miało niebagatelne znaczenie propagandowe i operacyjne.

Werbunek ochotników z Trynidadu i Tobago w szeregi tzw. Państwa Islamskiego skłania władze tego wyspiarskiego kraju do podejmowania działań 
prewencyjnych. Zjawisko to niepokoi również Stany Zjednoczone Ameryki, szczególnie w kontekście możliwości wykorzystania doświadczenia bojowników z rejonu Syrii i Iraku oraz ewentualności podjęcia przez nich działalności terrorystycznej wymierzonej w placówki dyplomatyczne USA w Ameryce Łacińskiej bądź nawet prób przeprowadzenia zamachu na terytorium USA, szczególnie w Miami i na Florydzie, którą od karaibskiego państwa nie dzieli przecież duża odległość - zaledwie trzy i pół godziny lotu.

Walka z terroryzmem była jednym $\mathrm{z}$ tematów rozmów prezydenta USA Donalda Trumpa z premierem Trynidadu i Tobago w sierpniu 2018 roku. Strategia antyterrorystyczna jest rozwijana w namacalny sposób dopiero od 2016 roku, a więc od okresu, kiedy uwidocznił się fenomen rekrutacji ochotników z tego regionu Karaibów do struktur tzw. Państwa Islamskiego. Procesy radykalizacji młodych przedstawicieli rodzimej społeczności muzułmańskiej skłoniły władze Trynidadu i Tobago do reformy instrumentów prawnych służących poprawie stanu bezpieczeństwa. Poważnym wyzwaniem był brak karalności akcesu do zagranicznych organizacji dżihadystycznych. Dopiero niedawno rząd Trynidadu i Tobago podjął inicjatywy mające na celu ograniczenie zagrożeń ze strony ekstremizmu. W trakcie mającej miejsce w styczniu 2016 roku w stolicy Jamajki XIV Konferencji Bezpieczeństwa Państw Karaibskich (CANSEC) przedstawiciel Trynidadu i Tobago zapowiedział wdrażanie specjalnych programów inkluzji społecznej, skierowanych do ludzi młodych. Programy te są podyktowane potrzebą zapobiegnięcia ich werbunkowi przez środowiska przestępcze i ekstremistyczne. Konieczność ich rozwijania jest oczywista; jej potrzebę wyrażają m.in. słowa admirała USA Kurta Tidda: „Władze Trynidadu powinny zrozumieć uwarunkowania, które sprawiają, że jednostki ulegają radykalizacji, by następnie być w stanie im przeciwdziałać" [Goi 2017].

Jedną z inicjatyw tego rodzaju jest Program Bezpieczeństwa Obywatelskiego (Programa de Seguridad Ciudadana - PSC), adresowany do osób mieszkających w ubogich dzielnicach trynidadzkich miast, takich jak Port of Spain. Jego celem jest powstrzymanie rozwoju przestępczości i przemocy. W lutym 2018 roku ogłoszono z kolei plan modyfikacji Ustawy Antyterrorystycznej, obejmujący walkę z finansowaniem terroryzmu oraz - przede wszystkim - penalizację udziału obywateli wysp w zagranicznych organizacjach ekstremistycznych [El extraño caso... 2018]. W tym samym roku, w maju, parlament Republiki Trynidadu i Tobago przyjął regulacje prawne, określane jako Ustawa przeciwko gangom, mające na celu poprawę efektywności zwalczania organizacji przestępczych.

Wiele z tych działań zostało podjętych we współpracy ze Stanami Zjednoczonymi Ameryki, które, jak wspomniano, dostrzegają wagę zabiegania rozwojowi ekstremizmu w strategicznym dla nich regionie. USA obligowały władze Trynidadu i Tobago do zaostrzenia mechanizmów penalizacji aktywności ekstremistycznej. Ważnym instrumentem północnoamerykańskiej polityki w regionie jest Inicjatywa Bezpieczeństwa Basenu Morza Karaibskiego (Caribbeean Basin Security Initiative - CBSI) obejmująca - obok Trynidadu i Tobago - m.in. Domi- 
nikanę, Jamajkę, Bahamy, Antiguę i Barbudę. W ramach tego programu od 2010 roku USA przeznaczyły dla państw regionu $437 \mathrm{mln}$ dolarów wsparcia [Caribbean Basin Security ... 2018]. Do głównych celów CBSI można zaliczyć walkę z przestępczością, handlem bronią, wspieranie władzy sądowniczej, działania na rzecz inkluzji społecznej i niwelowanie zagrożeń dla bezpieczeństwa. Warto zauważyć, że pomimo niewielkich rozmiarów Trynidad i Tobago jest dla Stanów Zjednoczonych Ameryki ważnym partnerem strategicznym w regionie (eksport gazu i ropy). Podczas podróży do krajów Ameryki Łacińskiej państwo to w 2009 roku wizytował prezydent USA Barack Obama, a w 2013 wiceprezydent Joe Biden.

Oczywiście większość muzułmanów zamieszkujących wyspy nie podziela ekstremistycznej kosmowizji i piętnuje terroryzm. Od dżihadyzmu jednoznacznie odcina się największa na wyspach organizacja skupiająca muzułmanów - Zjednoczona Islamska Organizacja Trynidadu i Tobago. Przedstawiciele społeczności muzułmańskiej protestowali np. w maju 2016 roku przed wizytą na Trynidadzie prezydenta Wenezueli Nicolasa Maduro. Powodem protestów było uwolnienie zatrzymanych w Wenezueli w 2014 roku pięciu obywateli Trynidadu i Tobago w związku z zarzutami dotyczącymi prowadzenia działalności terrorystycznej. Mieszkający na wyspach wyznawcy islamu niejednokrotnie zresztą wyrażali zaniepokojenie, że werbunek ochotników z Trynidadu i Tobago do tzw. Państwa Islamskiego może negatywnie wpłynąć na percepcję wyznawców islamu i przyczynić się do umocnienia negatywnych stereotypów dotyczących muzułmanów, rzeczywistym zaś wyzwaniem, z którym powinny się zmierzyć władze, jest niwelowanie nierówności społecznych i walka $\mathrm{z}$ oddziaływaniem subkultur przestępczych, oferujących ludziom młodym i wykluczonym poczucie afiliacji, nadzieję na poprawę egzystencji i będących nierzadko substytutem rodziny. Według raportu ONZ aż ok. 50\% Afrotrynidadczyków dorastało w rozbitych rodzinach [Thomas-Johnson 2016]. Mechanizmy funkcjonowania komórek terrorystycznych i gangów w różnych częściach świata wykazują zresztą spore podobieństwo w sensie oferowania poczucia przynależności, cementowania pierwotnych więzi społecznych i dookreślenia tożsamości.

Konkluzji powyższych rozważań towarzyszy świadomość, że idea tzw. Państwa Islamskiego nie ulegnie anihilacji wraz z jego rozbiciem na terenie Iraku i Syrii. Będący określoną kosmowizją dżihadyzm z pewnością nadal będzie inspirował jednostki do wzięcia udziału w „globalnej świętej wojnie”, w czym kluczową rolę będą odgrywać osobiste predyspozycje oraz uwarunkowania endoi egzogenne. Nie bez znaczenia okazuje się propagandowa stylizacja walki ukazywanej jako męska przygoda, która nadaje życiu sens i je odmienia. Terroryzm i ekstremizm polityczny często czerpią, jak wiadomo, zyski z działalności o charakterze przestępczym, tym bardziej więc zasadne są komplementarne inicjatywy podyktowane nie tylko potrzebą powstrzymania radykalizmu i ograniczenia zagrożeń płynących z jego strony, ale również wyrównywaniem szans środowisk najbardziej dotkniętych ekskluzją społeczną i łatwo ulegających oddziaływaniu grup przestępczych lub terrorystycznych. Przypadek dżihadystów z Trynidadu 
i Tobago egzemplifikuje mechanizmy związków doświadczania marginalizacji i trudności ekonomicznych z efektywnością aktywności werbunkowej organizacji prezentujących określony konstrukt ideowy. Wydaje się zatem, że konieczne będzie uruchomienie w tym państwie specjalnych programów deradykalizacyjnych i integracyjnych dla byłych bojowników tzw. Państwa Islamskiego, zaprojektowanych na podobieństwo programów resocjalizacyjnych, skierowanych do byłych członków gangów. Chociaż w wielu przypadkach socjalizacja do terroryzmu jest udziałem osób należących do klasy średniej, o czym świadczą np. biografie niektórych europejskich dżihadystów, to jednak należy pamiętać, że katalizatorami radykalizacji bywają determinanty społeczno-ekonomiczne. Przykład zwerbowanych przez tzw. Państwo Islamskie ochotników z Trynidadu i Tobago ilustruje w dużym stopniu te zależności.

\section{Title: The Phenomenon of Foreign Fighters from the Republic of Trinidad and Tobago in the Islamic State}

Summary: The main purpose of the paper is to analyse the phenomenon of so-called "foreign fighters" from the Republic of Trinidad and Tobago joining the Islamic State. It shows mechanisms and manifestations of the radical Salafism in this small Caribbean island country that became the jihadist recruiting ground. The article analyses the background of the activity of some radical groups and the terrorist cells that very often appeared in the symbiotic relationships with criminal gangs. The article refers to some social and economic conditions for violent radicalization in Trinidad and Tobago. It shows the most important dimensions of the counter-terrorism strategy implemented by the Trinidadian government now and in the past in the national and regional context.

Keywords: Trinidad and Tobago, jihadists, Islamic State, counter-terrorism, criminality

\section{BIBLIOGRAFIA}

1. Alonso L.F. (2016), Trinidad y Tobago va a empeorar la situación de seguridad, „Insight Crime", 8 de junio de 2016, s. 4.

2. Bolechów B. (2012), Polityka antyterrorystyczna w świetle badań nad terroryzmem, Wydawnictwo Uniwersytetu Wrocławskiego, Wrocław, s. 24, 33.

3. Caribbean Basin Security Initiative, 2018, U.S. Department od State, https://www.state.gov/p/ wha/rt/cbsi/ [dostęp: 25.09.2018].

4. Causwell X. (2018), Islamist Militancy in Trinidad \& Tobago: The Incubation of Terror, „George Town Security Studies Review", March 08, s. 24.

5. Combatientes de Trinidad y Tobago dentro del Estado Islámico, 20 de septiembre de 2017, http://www.infobae.com/america/mund...evo-desafio-para-el-caribe-y-america-del-sur/ [dostęp: 02.09.2018].

6. Connell C.C. (2004), Understanding Islam and its Impact on Latin America, Alabama, s. 29-31.

7. Cottee S. (2016), ISIS in the Caribbeean, „The Atlantic”, December 8, https://www.theatlantic. com/international/archive/2016/12/isis-trinidad/509930/ [dostęp: 25.09.2018]. 
8. Dawkins M. (2018), A Profile of the Caribbean Region: Recent Trends in Crime and Violence, [w:] Crime and Violence in the Caribbean. Lessons form Jamaica, red. S. V. Morris-Francis, C. A. Gibson, L. E. Grant, The Rowman \& Littlefild Publishing Group, London, s. 14.

9. El extraño caso de Trinidad y Tobago en el Caribe, fuente de enrolados en el Estado Islámico, SECINDEF. International Consulting, Security, Intelligence \& Defence, 28 de agosto de 2018, https://secindef.org/el-extrano-caso-de-trinidad-y-tobago-en-el-caribe-fuente-de-enrolados-en-el-estado-islamico/ [dostęp: 06.09.2018].

10. García-Calvo C. (2017), Las relaciones bilaterales España-Portugal en la lucha contra el terrorismo global y la prevención de la radicalización violenta, „ARI”, Real Instituto Elcano de Estudios Internacionales, s. 2.

11. Goi L. (2017), Trinidad struggles to stem youth recruiting by gangs, terror groups, „InSight Crime", February 23, s. 16.

12. Graham-Harrison E., Surtees J. (2018), Trinidad's jihadis: how tiny nation became Isis recruiting ground, „The Guardian”, February 2.

13. Halima-Sa'adia K. (2017), Regional Report: Historical and Contemporary Overview of Muslims in Trinidad and Tobago, July, s. 2. https://www.researchgate.net/publication/318405185/ download [dostęp: 23.09.2018].

14. Hunte M., Waldropt Bonair L.-A. (2010), Crime in Trinidad and Tobago: Trends and Implications, World Stustianable Development Outlook, s. 16.

15. Khan Z.A. (2013), Milestones in the History of Muslims in Trinidad and Tobago since 1845, St. Augustine, Trinidad, s. 35-42.

16. Kosmynka S. (2014), Echa terroryzmu islamistycznego w Ameryce Eacińskiej. Transformacje demokratyczne w Ameryce Lacińskiej, red. K. Krzywicka, Wydawnictwo Uniwersytetu im. Marii Curie-Skłodowskiej, Lublin, s. 142-143.

17. Lewandowska M. (2014), Trynidad i Tobago: zróżnicowanie etniczne a reprezentacja polityczna, „Ameryka Łacińska”, 1 (83), s. 79-80.

18. Lisocka-Jaegermann B. (2009), Czarne Ameryki, [w:] Dzieje kultury latynoamerykańskiej, red. M. F. Gawrycki, PWN, Warszawa, s. 169.

19. McCoy J., Knight, W. A. (2017), Homegrown Violent Extremism in Trinidad and Tobago: Local Patterns, Global Trends, „Studies in Conflict and Terrorism”, vol. 40, issue 4, s. 27. DOI: https:// doi.org/10.1080/1057610X.2016.1206734.

20. Sageman M. (2008), Leaderless Jihad. Terror Networks in the Twenty-First Century, University of Pennsylvania Press, Philadelphia, s. 29-31.

21. Seepersad R. (2016), Crime and Violence in Trinidad and Tobago, IDB Series on Crime and Violence in the Caribbean, Inter-American Development Bank, June, s. 86-87.

22. Terdman M. (2010), Caribbean Basin, [w:] Guide to Islamist Movements, red. B. Rubin, vol. 1, New York, s. 575.

23. Thomas-Johnson A. (2016), Caribbean to 'Caliphate': On the trail of the Trinidadians fighting for the Islamic State, „Middle East Eye”, 22 November, s. 5.

24. Tofik Karam J. (2011), Historias musulmanas en América Latina y el Caribe, „Istor: Revista de historia internacional", no. 45 , s. 38. 